DOI: https://doi.org/10.36910/6775-2524-0560-2021-43-08

УДК 510

${ }^{1}$ Корінчук Наталія Юріївна

https://orcid.org/0000-0001-7977-0654

${ }^{1}$ Бойчук Марія Федорівна

${ }^{1}$ Нарихнюк Наталія Юріївна

${ }^{2}$ Корінчук Володимир Васильович

https://orcid.org/0000-0003-1084-6897

${ }^{1}$ Комунальний заклад вищої освіти «Луцький педагогічний коледж» Волинської обласної ради.

2 Луцьке вище професійне училище будівництва та архітектури.

\title{
ІНФОРМАЦЙНО-КОМП'ЮТЕРНИЙ АСПЕКТ РОЗВИТКУ МАТЕМАТИЧНИХ ТА ПРОФЕСІЙНИХ КОМПЕТЕНТНОСТЕЙ СТУДЕНТІВ В УМОВАХ ДИСТАНЦІЙНОГО НАВЧАННЯ
}

\begin{abstract}
Корінчук Н.Ю., Бойчук М. Ф., Нарихнюк Н. Ю., Корінчук В.В. Інформаційно-комп’ютерний аспект розвитку математичних та професійних компетентностей студентів в умовах дистанційного навчання. У статті розглядається проблема використання студентами і учнями онлайн ресурсів та інших інформаційно-комп'ютерних технологій, їх доступність і вплив на рівень знань при вивченні математики під час дистанційного навчання в умовах карантину. 3 цією метою авторами було проведене анкетування серед студентів Луцького педагогічного коледжу та учнів Луцького вищого професійного училища будівництва та архітектури на предмет використання ними онлайн ресурсів та освітніх електронних сервісів і наводиться детальний порівняльний аналіз результатів цих соціологічних досліджень між двома закладами освіти.

Ключові слова: освітня платформа, класрум, ноутбук, онлайн ресурси, дистанційне навчання, оволодіння навиками користування інформаційно-комп'ютерними технологіями, формування математичних знань, навичок і умінь.
\end{abstract}

Коринчук Н.Ю., Бойчук М. Ф., Нарихнюк Н. Ю., Коринчук В.В. Информационно-компьютерный аспект развития математических и профессиональных компетентностей студентов в условиях дистанционного обучения. В статье рассматривается проблема использования студентами и учениками онлайн ресурсов и других информационнокомпьютерных технологий, их доступность и влияние на уровень знаний при изучении математики при дистанционном обучении в условиях карантина. С этой целью авторами было проведено анкетирование среди студентов Луцкого педагогического колледжа и учащихся Луцкого высшего профессионального училища строительства и архитектуры на предмет использования ими онлайн ресурсов и образовательных электронных сервисов, а также приводится подробный сравнительный анализ результатов этих социологических исследований между двумя учебными заведениями.

Ключевые слова: образовательная платформа, классрум, ноутбук, онлайн ресурсы, дистанционное обучение, овладение навыками пользования информационно-компьютерными технологиями, формирование математических знаний, навыков и умений.

Korinchuk N.Yu., Boychuk M.F., Narikhnyuk N.Yu., Korinchuk V.V. Information and computer aspect of the development of mathematical and professional competencies of students in distance learning. The article considers the problem of students and students using online resources and of the information and computer technologies, the iravailability and impacton the level of know ledge in the study of mathematics during distance learningin quarantine.To thisend, the authors conducted surve yamong students of Lutsk Pedagogical College and students of Lutsk Higher Vocational School of Construction and Architecture for the iruse of online resource sand educational electronic service sand provides a detailed comparative analysis of the sesociological studies between the two educational institutions.

Keywords:educational platform, classroom, laptop, online resources, distance learning, mastering the skills of using information and computer technologies, formation of mathematic alknowledge, skills and abilities.

Постановка проблеми. Дистанційне навчання стає все більше і більше популярним з кожним роком і за кордоном, і в Україні. Вже не перший рік ми спостерігаємо сталий інтерес до дистанційного навчання широких мас населення України. Одним 3 напрямів освітніх інновацій, що активно розвиваються та безпосередньо скеровані на вдосконалення освітнього процесу й підвищення якості освіти, $\epsilon$ інформатизація освіти. Найважливішою ланкою цього процесу стало опанування технологій навчання із застосуванням в освітньому процесі комп'ютерів. Водночас відбуваються зміни змісту та методики навчання, тобто формуються та розвиваються новітні інформаційні освітні технології. У сучасних умовах інформаційні освітні технології є невід'ємним складником освітнього процесу, в тому числі дистанційного навчання.

Використання різних освітніх платформ та онлайн ресурсів створює підгрунтя для оволодіння студентами та учнями вміннями самостійно набувати предметні компетентності, розвиває самостійність студентів та учнів в освітній діяльності, сприяє самовдосконаленню, самоорганізації та самоконтролю здобувачів світи. 
Впровадження новітніх освітніх технологій мотивує здобувачів освіти, сприяє формуванню пізнавального інтересу студентів та учнів, позитивно впливає на зацікавленість до навчальних дисциплін, допомагає через інформаційно-цифрові компетентності формувати математичні та інші предметні компетентності, потрібні у суспільному та в особистому житті здобувачів освіти.

У зв'язку з цим проблема використання онлайн ресурсів та інформаційно-комунікаційних технологій під час дистанційного навчання в умовах карантину при вивченні природничоматематичних предметів була і $€$ актуальною.

Аналіз останніх досліджень і публікацій. Офіційно дистанційне навчання в Україні було запроваджено у 2004 році. 21 січня 2004 року було видано наказ №40 Міністерства освіти і науки України. Цим наказом було затверджено «Положення про дистанційне навчання» [1, 2 ]. Цю дату можна вважати датою запровадження новітніх освітніх технологій.

Першим учителем дистанційного навчання можна вважати Салман Хана. Спочатку він в мережі інтернет розміщував свої відео-заняття для своїх родичів у вільному доступі. Ці заняття у мережі інтернет отримали мільйони переглядів і стали надзвичайно популярними в усьому світі. Тому Салман Хан створив перший великий дистанційний центр навчання, який назвали Хан-Академія. Далі було створено великий освітній центр YouTube Хан, веб сторінки якого перекладені на багатьох мовах світу.[3].

В Україні за допомогою дистанційної форми навчання проводиться підготовка абітурієнтів до вступу на університетських курсах. Також створено великі освітні центри, які готують учнів до здачі ЗНО за допомогою дистанційної форми навчання. Найбільшим таким центром отримання знань дистанційно за допомогою онлайн-курсів можна вважати Prometheus. [5].

Для тих учнів, які перебувають за територією України, була створена у 2007році державна Міжнародна українська школа. У цій школі здобувачі освіти мають можливість отримати початкову освіту, базову освіту та повну середню освіту. Форма організації навчання у цій школі - дистанційна та екстернатна. Випускники отримують свідоцтва та атестати державного зразка.

Для організації індивідуального навчання українських школярів, які не можуть відвідувати школи, в Україні створено приватні школи, навчання у яких здійснюється дистанційно або за допомогою екстернатної форми навчання. [6].

Майже два десятиріччя впроваджується в Україні дистанційна форма освіти. Початком відліку став 2002 рік. У цьому році було розпочато експеримент із дистанційної форми навчання. Урядом України у 2003 році була затверджена Програма розвитку системи дистанційного навчання.[7]. Вектори програми були визначені у Положенні про дистанційне навчання, яке було затверджене МОН України у 2004 році.

Першу ліцензію в Україні на провадження освітньої діяльності у закладі загальної середньої освіти у дистанційній формі отримав Центр освіти «Дистанційна школа «Оптіма» [8].

У минулому 2020 році МОН України було затверджене нове Положення про дистанційне навчання. Це дало можливість українським здобувачам освіти одержати якісні освітні послуги в умовах карантину.[9 ].

До 2019-2020 навчального року вже у 182 школах України учні мали можливість навчатись на дистанційній формі. У 2021 році 233 школи в Україні мають можливість і надають освітні послуги дистанційно. Це заклади загальної середньої освіти як комунальної форми власності так і приватної форми власності. $\mathcal{C}$ на Україні 19 приватних шкіл, які проваджують освітню діяльність тільки за дистанційною формою.

Інструкції із використання освітніх платформ можна знайти на сайті Міністерства освіти i науки України та в Інтернеті. У листі Міністерства освіти та науки України від 26 березня 2020 року № 1/9-177 «Щодо організації освітнього процесу в закладах професійної (професійно-технічної освіти на період карантину)» [10] наведено перелік електронних сервісів для організації дистанційного навчання.Їх можна нарахувати більше десятка. Серед них:

1. Moodle. Ця система дозволяє організувати в онлайн-форматі освітню платформу. Систему можна використовувати для організації дистанційного навчання. Системою зручно користуватись учням, студентам, учителям, викладачам та адміністраторам.

2. Доступна безкоштовно: Google Клас (Google Classroom). Багатофункціональна безкоштовна система, яка дає можливість миттєво обмінюватись інформацією між тими, хто навчає і тими, хто навчається. Сервіс дає можливість одночасно використовувати і сховище, i документи, і пошту. 
3. Google Презентації (Google Presentations). Цей додаток використовує операційну систему Android. Користувачі мають можливість працювати із файлами, презентаціями. Презентації можна створювати, додавати слайди, редагувати, форматувати, надавати доступ іншим учасникам освітнього процесу, обмінюватись коментарями. Цей додаток може частково функціювати без підключення до мережі Інтернет.

4. iLearn. Ця платформа $є$ безкоштовною, із використанням ігрових методів для виконання тестів, проходження вебінарів та онлайнкурсів.

5. Kahoot! За допомогою цього сервісу можна організовувати перевірку і оцінку знань здобувачів освіти. Сервіс дає можливість складати тести і виконувати їх в ігровій формі. Використовувати можна прямо у браузері;

6. Edmodo. Це спеціальний освітній сайт, принцип побудови, якого здійснено подібно до принципу побудови соціальної мережі Facebook. За допомогою даного сайту учасники освітнього процесу мають можливість швидко обмінюватися інформацією.

7. LearningApps.org. За допомогою цього сервісу користувач має можливість конструювати інтерактивні завдання.

8. Stepik. Дана освітня платформа є безкоштовною. Користувач за допомогою конструктора може створювати відкриті уроки та відкриті онлайнкурси.

9. OnlineTestPad. Онлайн конструктор тестів, опитувань, кросвордів.

10. Месенджери Skype, Viber, WhatsApp, Zoom. Дають можливість спілкуватись у реальному часі

викладачам і студентам.

«Дистаниійна освіта підходить у першу чергу для високовмотивованої дитини. Таких у нас не більше 10-15 відсотків. Що стосується інших, то з ними, чесно кажучи, й інші методи навчання не дуже спрачюють. Але якщо ие «живий» клас, то вчитель може хоч якось проконтролювати, певним чином змусити учня зробити хоча б щось елементарне. Також є шанс, що учень мимоволі хоч щось запам'ятає, тому що інші учні праџюють. 3 дистаниійним навчанням таке не спрацює, $і$ якщо немає підтримки з боку сім' '̈̈, то зрозуміло, щя ефективність буде вкрай низькою або навіть нульовою. Тому проблема мотиваиії для України стоїть дуже гостро» - зазначає відомий педагог і шеф-редактор порталу «Освітня політика» Віктор Громовий. [11].

Український центр якості освіти провівши та зробивши аналіз свого соціологічного дослідження зазначає, що педагоги під час дистанційного навчання використовують декілька каналів для зв'язку з учнями та студентами. У переважній більшості спілкуються з учнями та студентами за допомогою повідомлень (Viber, Whatsapp, Telegram, Messenger ) - 83\% учасників освітнього процесу. Засоби відеоконференцій на зразок Zoom, Skype використовують 75\% учасників освітнього процесу. Можливостями електронної пошти для надсилання і отримання завдань користуються 39\%. Google Classroom, Moodle для навчання регулярно використовують 71\%. I понад 63\% учасників освітнього процесу для дистанційного навчання використовують телефонний зв'язок.

В освітніх закладах України в освітньому процесі ще не достатньо застосовують електронні щоденники та електронні журнали. Було проведено опитування, яке показало, що тільки 3,6\% (164 освітні заклади) у навчанні впровадили Модуль E-Journal. На інших платформах використовують електронний щоденник та електронний журнал всього $30 \%$ освітніх закладів. $67 \%$ шкіл України, як указали керівники, не мають належного технічного забезпечення i мережі Інтернет i тому не практикують електронний щоденник та електронний журнал під час навчання.

У 2020 році тільки у 256 вчителів, що становило $0,6 \%$ опитаних, під час впровадження дистанційного навчання, не було ніяких труднощів. У 2021 році вже $48 \%$ вчителів, які брали участь в опитуванні, зазначили, що вони детально оволоділи технологіями дистанційного навчання.

Метою дослідження стало визначення рівня психологічної комфортності студентів і здатності до самоорганізації за період карантину та вплив дистанційного навчання на рівень знань студентів та учнів.

Невирішені частини проблеми. Перед сучасною дидактикою постають проблеми в організації новітнього освітнього процесу в умовах карантину, використання ефективних методів та засобів навчання. Водночас, більшість проблем залишилися невирішеними. Так, під час опитування, зробленим українським центром якості освіти, 3'ясувалось, що для ефективного впровадження дистанційного навчання необхідно вирішити такі питання. 
1. Між учасниками освітнього процесу організовувати взаємодію. Як вказали $72 \%$ керівників шкіл, під час дистанційного навчання, не всі учні відвідують онлайн-уроки, не всі учні мають інтернет, щоб вийти на зв'язок, не всі учні виконують домашні завдання.

2. Розв'язати проблему із технічним забезпеченням. Як вказали $62 \%$ керівників шкіл у більшості учнів та багатьох учителів відсутні технічні засоби та інтернет-зв'язок для дистанційного навчання. У багатьох, особливо сільських школах, низька швидкість інтернет-зв'язку (47\%). Під час опитування батьків учнів з'ясувалось, що у 8,8\% сім'ях немає комп'ютера. На недоліки в інтернетзв’язку вказали $22 \%$ родин. Також $53 \%$ учителів вказують недоліки технічного забезпечення.

3. Вирішити питання методичної підготовки педагогів. Опитування показало, що 47\% учителів до карантину не практикували елементів дистанційного навчання. На жаль, серед опитаних освітян, виявились такі, що не володіють інформаційно-комунікаційними технологіями навчання.

Основні результати досліджень. Сьогодні особливої актуальності набуває проблема ретельного планування діяльності викладача та учнів, що робить прогнозування результатів навчання більш обгрунтованим. 3'ясовано в цілому, що ситуація вимушеного карантину не додала особливих ознак стресу й психологічного напруження у студентів та учнів. Проте ситуація навчання під час карантину емоційно та гостро відчувається здобувачами освіти. Дистанційне навчання для значної частини учасників освітнього процесу стало каталізатором для удосконалення навичок самостійної роботи, навичок самоосвіти. Під час дистанційного навчання в умовах карантину здобувачі освіти по новому навчались планувати, організовувати свою освітню діяльність, розподіляти час для онлайннавчання і для самоосвіти.

Викладачі наших навчальних закладів користувались переважно освітньою платформою GoogleClassroom, яка на їхню думкою $є$ найбільш поширеною і практичною. Хоча в умовах дистанційного навчання учні і студенти, а також викладачі та батьки зіткнулися з певними труднощами та проблемами. Як наслідок, це призвело до впливу на зниження успішності студентів та учнів, втрати інтересу до навчання. В цих умовах набуває важливого значення мотивація як важливий компонент освіти. Ефективність будь-якого виду освітнього процесу безпосередньо пов'язана з рівнем навчальної мотивації. Особливістю навчання, зокрема дистанційного, є те, що змусити вчитися не можна, передусім необхідна наявність у студента та учня бажання, що і є мотивацією навчальної діяльності.

На основі матеріалів опитування щодо організації дистанційного навчання, яке було проведене, Державною службою якості освіти України з 2 по 9 лютого 2021 року, участь у якому взяли понад 270 тисяч респондентів, із них близько 68 тисяч учнів 9-х - 11-х класів, 158 тисяч батьків і 47,5 тисяч освітян (43 тисячі вчителів і 4,5 тисячі керівників закладів освіти) авторами було проведене своє соціологічне дослідження. Анкетуванням було охоплено 208 студентів Луцького педагогічного коледжу та 94 учня Луцького вищого професійного училища будівництва та архітектури перших та других курсів навчання.

Анкета, яку підготували викладачі, складається із десяти запитань, до яких пропонувались для вибору студентами та учнями відповіді. Результати відповідей на кожне з них наводяться нижче.

1. Першим питанням анкетування автори намагались вивчити ступінь завантаження студентів та учнів навчальними предметами для вивчення. Кожен четвертий студент як Луцького педагогічного коледжу та так і учень Луцького вищого професійного училища будівництва та архітектури відмітили, що вивчали під час дистанційного навчання від 16 до 20 навчальних предметів. Однак, були і такі $5 \%$ студентів коледжу та $22 \%$ учнів училища, які виходили на зв'язок лише від одного до п'яти предметів. Жоден із учнів та студентів не вивчав більше 25 навчальних дисциплін. Переважна більшість студентів та учнів вивчали від 11 до 15 предметів.

2. На запитання: «Які ресурси та програми використовували під час навчання в режимі «викладач-студент» та «студент-викладач» 57\% студентів коледжу та $93 \%$ учнів училища відповіли, що для передавання чи отримання інформації використовували електронну платформу GoogleCIassroom. Кожен третій студент коледжу та кожен п'ятий учень училища спікувались в Zoom. Рідше студенти коледжу всього 7\% спілкувались через Viber, хоча $57 \%$ учнів училища для отримання і передачі інформації використовували цей сервіс. Хотілось би зазначити, що жоден студент та учень не використовував такий сервіс як Skype та лише по 2\% студентів та учнів використовували Facebook (Messenger) i Telegram.

3. $47 \%$ студентів коледжу та лише $7 \%$ учнів училища не стикалися 3 труднощами під час навчання з використанням дистанційних технологій в умовах карантину. Слід зазначити, що лише у $8 \%$ студентів коледжу відсутня потрібна техніка вдома (комп'ютер чи ноутбук), тоді як серед учнів 
училища цей відсоток становить близько сорока. 8\% студентів коледжу вказували в анкеті на відсутність необхідних навичок роботи 3 технікою та програмним забезпеченням, то серед учнів училища було $31 \%$. Було складно підлаштуватись до занять у визначений час $7 \%$ студентам коледжу та майже кожному другому учню училища. Останні пояснювали такий стан зайнятістю домашнім господарством та роботами.

4. У відповідь на запитання: «Скільки часу на день в середньому у вас займала комунікація (спілкування) з викладачем», то кожен другий студент коледжу і кожен п'ятий учень училища написали від 30 хвилин до 1 години. Слід відмітити, що 6\% студентів коледжу та 18\% учнів училища не робили цього, тобто не спілкувались, пояснюючи відсутністю техніки чи Інтернету. Більше двох годинна спілкування з викладачем приділяли $24 \%$ студентів коледжу та лише $4 \%$ учнів училища.

5. Чи впливало негативно дистанційне навчання на рівень моїх знань, то $8 \%$ студентів коледжу і 13\% учнів училища відповіло, що саме «так». Кожен другий студент коледжу та кожен третій учень училища сказали, що не вплинуло негативно на рівень їхніх знань. Решта студентів та учнів повідомляли про частковий вплив.

6. Кожен третій студент коледжу та кожен сьомий учень училища підтвердили, що дистанційне навчання позитивно вплинуло на рівень їхніх знань. 18\% студентів та $21 \%$ учнів відмічало, що ніякого позитивного впливу не відчули, а решта частково відчували цей вплив.

7. Майже $20 \%$ студентів та $13 \%$ учнів відзначало, що дистанційне навчання ніяк не вплинуло на рівень їхніх знань. Кожен четвертий студент та кожен п'ятий учень училища повідомляли про протилежне твердження.

8. На запитання: «Чи подобається навчатись вдома?», половина студентів коледжу та $43 \%$ учнів училища відповіли позитивно. Кожному сьомому студенту коледжу та кожному четвертому учню училищу некомфортно навчатись вдома. Однак, $33 \%$ студентам та $31 \%$ учням подобається частково навчатись вдома.

9. Кожен п'ятий студент та кожен четвертий учень позитивно відповіли на запитання: «Чи не виникає у вас бажання повернутися до звичайних занять у навчальному закладі?». У майже половині як студентів так і учнів виникало таке бажання. $24 \%$ студентів та $28 \%$ учнів заперечили таке бажання, як повернення до навчання у навчальному закладі.

10. Майже кожен третій студент коледжу та кожен четвертий учень училища хотіли б скористатися можливістю перезарахувати (перездати офлайн) результати дистанційного навчання, які вивчалися на онлайн платформах. 35 \% студентів коледжу та $29 \%$ учнів училища заперечують таку можливість. Але кожен третій студент і майже половина учнів можливо б скористувались цією нагодою.

Висновки. Понад 70\% педагогів і 80\% батьків вважають дистанційне навчання менш ефективним, ніж безпосереднє навчання у навчальному закладі. Про це йдеться в аналітичній довідці щодо організації дистанційного навчання в школах у 2020/21 навчальному році, створеній за результатами анонімного онлайн-анкетування учасників освітнього процесу.

Після проведеного дослідження, ми прийшли до таких висновків, що для ефективності освітнього процесу треба подолати проблеми дистанційного навчання, а саме - це брак досвіду як у окремих викладачів так і значної частини студентів та учнів щодо використання спеціальних навчальних програм та електронних платформ і відсутність досвіду щодо організації дистанційного навчання. На думку опитаних серед чинників, які найбільше впливають негативно на ефективне навчання із застосуванням інформаційних технологій, значна частина опитаних назвала обмежений доступ до інтернету, відсутність цифрових пристроїв і недостатню цифрову інфраструктуру як вдома так і в закладі освіти. Окрім того серед факторів, що впливають на недостатню якість дистанційного навчання, є низька мотивацію учнів та студентів.

\section{Пропозиції.}

1.Налагодження ефективної взаємодії всіх учасників освітнього процесу «викладач - студент», «студент - викладач». Бо як показало опитування не всі учні та студенти мають можливість вийти на зв'язок в Інтернеті, брати участь у відео-уроках, відео конференціях.

2.Технічне забезпечення як викладачів так і студентів та учнів, які в анкеті вказали на відсутність необхідної техніки вдома та на низьку швидкість інтернет-зв'язку. А це все в сукупності впливає на рівень знань студентів та учнів. 
1. https://zakon.rada.gov.ua/laws/show/z0464-04\#Text.Положення про дистанційне навчання, Наказ МОН № 40 від 21 січня 2004 року.

2. Станом на 2019 рік чинним є Положення, затверджене наказом МОН за № 466 від 24 квітня 2013 року.

3. Академія Хана - як зробити освіту цікавою та доступною? відео ресурс для навчання. buki.com.ua. Процитовано 2016-09-19.

4. Математика. Газета для вчителів математики. №9-10. 2020p.c 62-63.

5. Prometheus - масові безкоштовні онлайн-курси» Про проект. prometheus.org.ua.

6. https://web.archive.org/web/20171216140837/http://ukrintschool.org.ua/ old/ $\quad$ Apхівовано $16 \quad$ грудня 2017 у WaybackMachine. Курси Міжнародної української школи.

7. https://zakon.rada.gov.ua/laws/show/1494-2003-\%D0\%BF\#Text Про затвердження Програми розвитку системи дистанційного навчання на 2004-2006 роки], Кабінет Міністрів України.

8. https://don.kyivcity.gov.ua/files/2015/7/3/57.pdf. ПЕРЕЛІК навчальних закладів та суб'єктів господарювання, які отримали ліцензії на провадження освітньої діяльності, Департамент освіти і науки виконавчого органу Київської міської ради (Київської міської державної адміністрації).

9. https://mon.gov.ua/ua/npa/deyaki-pitannya-organizaciyi-distancijnogo-navchannya-zareyestrovano-v-ministerstviyusticiyi-ukrayini-94735224-vid-28-veresnya-2020-roku Деякі питання організації дистанційного навчання (зареєстровано в міністерстві юстиції України №941/35224 від 8 вересня 2020 року)], Міністерство освіти і науки України.

10. https://mon.gov.ua/ua/npa/shodo-organizaciyi-osvitnogo-procesu-v-zakladah-profesijnoyi-profesijno-tehnichnoyi-osvitina-period-karantinu. Лист міністерства освіти та науки України 26 березня 2020p. №1/9-177. Щодо організації освітнього процесу в закладах професійної (професійно-технічної) освіти на період карантину.

11. http://uc.kr.ua/2020/04/21/niyakoyi-osvitnoyi-katastrofy-ne-stanetsya/.

\section{References}

1. https://zakon.rada.gov.ua/laws/show/z0464-04\# Text. Regulations on distance learning, Order of the Ministry of Education and Science № 40 of January 21, 2004.

2. As of 2019, the Regulation approved by the order of the Ministry of Education and Science under № 466 of April 24, 2013 is valid.

3. Khan Academy - how to make education interesting and accessible? video resource for learning. buki.com.ua. Cited 201609-19.

4. Mathematics. Newspaper for math teachers. №9-10. 2020p 62-63.

5. Prometheus - mass free online courses $»$ About the project. prometheus.org.ua.

6. https://web.archive.org/web/20171216140837/ http://ukrintschool.org.ua/old/ Archived December 16, 2017 in WaybackMachine. Courses of the International Ukrainian School.

7. https://zakon.rada.gov.ua/laws/show/1494-2003-\%D0\%BF\#Text On approval of the Distance Learning Development Program for 2004-2006], Cabinet of Ministers of Ukraine.

8. https://don.kyivcity.gov.ua/files/2015/7/3/57.pdf. LIST of educational institutions and business entities that have received licenses to conduct educational activities, the Department of Education and Science of the executive body of the Kyiv City Council (Kyiv City State Administration).

9. https://mon.gov.ua/ua/npa/deyaki-pitannya-organizaciyi-distancijnogo-navchannya-zareyestrovano-v-ministerstviyusticiyi-ukrayini-94735224-vid-28-veresnya-2020-roku Some questions of the organization distance learning (registered in the Ministry of Justice of Ukraine №941 / 35224 of September 8, 2020)], Ministry of Education and Science of Ukraine.

10. https://mon.gov.ua/ua/npa/shodo-organizaciyi-osvitnogo-procesu-v-zakladah-profesijnoyi-profesijno-tehnichnoyi-osvitina-period-karantinu. Letter from the Ministry of Education and Science of Ukraine March 26, 2020 №1 / 9-177. Regarding the organization of the educational process in institutions of professional (vocational and technical) education for the period of quarantine.

11. http://uc.kr.ua/2020/04/21/niyakoyi-osvitnoyi-katastrofy-ne-stanetsya 